\title{
SOCIAL AND ECONOMIC EMASCULATION AS CONTRIBUTING FACTORS TO GANGSTERISM ON THE CAPE FLATS ${ }^{1}$
}

Llewellyn LM MacMaster

Stellenbosch University

\begin{abstract}
Gangsterism has been a part of the communities of the Cape Flats since the establishment of these townships under apartheid laws such as the Group Areas Act (1950) and its "twin partner", the Population Registration Act (1950). Gangsterism is a systemic phenomenon, rooted in multiple socio-economic and political causes, and it affects the lives of individuals, families and whole communities. This paper looks at two very particular aspects that contribute to the formation and continued existence of gangsterism, namely social and economic emasculation. A gender perspective provides a different angle that may broaden our understanding of gang formation in a new way. The article also will show how easy it is for leaders of gangs and drug lords to gain authority and power in communities characterised by poverty and unemployment as a result of economic exclusion. Faith communities in general and pastoral carers in particular need a holistic understanding of these and other factors related to gangsterism in order to play any meaningful role in addressing or eradicating gangsterism.
\end{abstract}

Key words: Criminal economy, Emasculation, Gangsterism, Psycho-systemic approach

\section{Introduction}

For the purpose of this paper I will not give a general discussion of gangs, but will focus on two specific aspects that contribute to the formation and continued existence of gangsterism on the Cape Flats. ${ }^{2}$ Using Elaine Salo's gender perspective on ganging practices ${ }^{3}$, I will show how a process of social and economic emasculation has contributed to the formation and ongoing existence of gangs. I will furthermore try to point out how a "criminal economy" has developed on the Cape Flats linked to drug lords and gang bosses, and how this is viewed by many as a "rational response of survival and resistance." For this purpose I will use a paper by André Standing entitled "The Social Contradictions of Organised Crime on the Cape Flats". 4

1 Paper read at Stellenbosch University and Protestant Theological University Kampen consultation on "Human dignity at the edges of life" at Stellenbosch, 14-15 August 2006.

2 Black and coloured townships south-east of the central business district of Cape Town are normally referred to as the Cape Flats (or "The Flats"). They have also been described as "apartheid's dumping ground". Through social engineering under apartheid, people classified as "non-White" were forcibly removed from more central urban areas designated for "White" people by way of race-based legislation such as the widely despised Group Areas Act (1950).

3 Salo, Elaine 2005. “"Mans is Ma Soe': Ganging Practices in Manenberg, South Africa and the ideologies of masculinity, gender and generational relations." Paper delivered at the Criminal Justice: A New Decade, Consolidating Transformation Conference, held 7-8 February 2005, Johannesburg. 21 March 2006. http://www.wits.ac.za/csvr/confpaps/salo.htm

$4 \quad$ Institute for Security Studies, Occasional Paper 74, June 2003. 3 March 2006. http://www.iss.co.za/Pubs/Papers/74/Paper 74.html 
In the final part of the paper I will very briefly put forward some of the challenges that gangsterism presents to faith communities from a pastoral or practical theological perspective.

\section{Some Background Information on Gangs}

1. Gangsterism or the existence of gangs is a global phenomenon. Spergel, for example, writes:

Youth gangs have existed in Western and Eastern societies for centuries. Most recently they have been reported in England, Scotland, Germany, Italy, Russia and other republics of the former Soviet Union, Bosnia (formerly part of Yugoslavia), Albania, Kenya, Tanzania, South Africa, Mexico, El Salvador, Brazil, Peru, Taiwan, South Korea, Japan, Hong Kong, Australia, New Zealand, The People's Republic of China an Papua New Guinea. Youth gangs are present in socialist and free-market societies, in developing and developed countries. ${ }^{5}$

2. Some communities on the Cape Flats have experienced the reality of street gangs for many decades. One of the first gangs in Cape Town, Globe, can be traced back to 1937 in the old District Six. Over the years gangs like the Americans (with affiliates like Young Americans, Ugly Americans, United Americans and Sexy Americans), the Hard Living Kids (HLs), Sexy Boys, Dixie Boys, Yuru Cats, Laughing Boys, the Born Free Kids (BFKs), Scorpions, Cisco Yakkies, Sicilians, Cape Town Scorpions (CTS), Naughty Boys, Nice Time Kids, Junky Funky Kids and Corner Boys have become household names in the various townships on the Cape Flats. In recent times we have seen American gangster rap-influenced spin-offs such as the Westsiders, Eastsiders or No Fears prevalent in schools, "where the gang rivalries of fathers, uncles and elder brothers play themselves out."

3. How many people belong to these gangs? It is very difficult to determine the precise number because of, among other things, strict codes of secrecy among gangs. However, some estimate the number of gangsters to be between 80000 and $100000 .^{7}$

4. When one pages through Cape Town newspapers covering the period 1989 to 1998 , headlines and reports indicate the reality of gangs on the Cape Flats. ${ }^{8}$ In a series of articles on the gangs in the Cape Peninsula Mariana Brand writes that nowhere in South

5 Spergel, IA 1995. The Youth Gang Problem: A Community Approach. New York, NY: Oxford University Press, 3.

6 "A Brotherhood sealed in Blood." Mail and Guardian, 2 August 2002.

7 Cf. Pinnock, Don 1982. The Brotherhoods: Street Gangs and State Control in Cape Town. Cape Town: David Phillip; Kinnes, Irvin. 2000. From Urban Gangs to Criminal Empires: The Changing Face of Gangs in the Western Cape. ISS Monograph Series No. 48. Halfway House: Institute for Security Studies. http://www.issafrica.org/Pubs/Monographs/No48/Contents.html

8 Some examples from Die Burger are: "Bendegevegte in die Kaapse Skiereiland is 'n alledaagse ding" (18 October 1989); “... meer as sestig bendes wat inwoners van die Kaapse Vlakte dekades terroriseer en vir wie menselewens nie meer 'n duit werd is nie" (21 April 1990); "Die Kaapse Vlakte wat deur bendes geteister word, staan by menige inwoner bekend as die "Vlakte van Verdriet"' (13 July 1990); "Bendes voer 'n skrikbewind op die Kaapse Vlakte." (10 October 1990); "Regters versoek dat die regering kyk na bendegeweld" (2 August 1994); "Bendegeweld vier hoogty in Elsiesrivier" (3 November 1994); "Amptelike syfers dui daarop dat Kaapstad en omstreke die hoogste misdaadsyfer in die land het ... Kaapstad is een van die gevaarlikste plekke ter wêreld." "Die Kaapse geweldadige bendes het reeds wêreldberigtheid verwerf ... Die bendestelsel is so diep verwortel." (20 March 1998); "Die bendekultuur is al só diep gewortel, en só baie mense se welvaart hang daarvan af." (14 April 1998). I use article headings from Die Burger because they aptly describe the situation under discussion. The other two Cape daily newspapers, The Cape Times and Cape Argus also reflect the same stories on gangs and gang activities. Two recently established tabloids, The Daily Voice and Die Kaapse Son, focus even more on gang-related stories than the so-called mainstream newspapers. 
Africa does one find a gang culture similar to that on the Cape Flats. ${ }^{9}$ A large number of gangs operate in a very well-structured fashion. They have well-defined hierarchical structures, strict internal discipline and enjoy strong loyalty from their members.

5. The existence of gangsterism on the Cape Flats cannot be viewed in isolation from the "culture of violence" 10 that is rooted in the history of this country. ${ }^{11}$

6. Defining Gangs: It is not easy to define gangs. The traditional view of gangs includes, inter alia, the designation "skollies", referring to those who operate within the Coloured $^{12}$ communities on the Cape Flats, as well as the so-called "tsotsi" culture that developed during the 1950 s with the establishment of Black African urban townships. According to Kinnes this understanding of gangs has changed considerably as street gangs have become more organised. ${ }^{13}$

Considering the contributions of Kinnes (2000), Gastrow (1998) ${ }^{14}$ and Pinnock (1982), the following "characteristics" of gangsters emerge:

- Gang members may range in age from youngsters ("corner kids") to adults between 20 and 40 years of age;

- The nature and activities of gangs are mainly determined by their social context;

- Membership of gangs may include persons both inside and outside of jails;

- Gang members may be anything from street-level operators to sophisticated syndicate bosses;

- They may belong to the category regarded by the government and its agencies as being at risk of becoming involved in criminal activities, or may make a choice to become involved, fully cognisant of the risks;

- Gangs may be involved in criminal activities for the sake of survival, or may be high-level, structured criminal organisations.

There has been an upsurge of gang-related violence on the Cape Flats since the beginning of 2005. Most community workers and police experts attribute this upsurge to ei-

9 Die Burger, September 1993.

Vogelman, L and Simpson, G 1991. "A Legacy of Youth Violence Haunts Apartheid." Psychology International. Vol. 1/2 1991. 3 March 2006. http://www.csvr.org.za/articles/artlvgs.htm

11 MacMaster, Llewellyn, LM 2005. "Violence and Christian Faith: A (never-ending) Spiral of Violence? Trying to shake off our violent past." In Van Keulen, Dirk and Martien E Brinkman (eds.) 2005. Studies in Reformed Theology 10. Christian Faith and Violence. Zoetemeer: Meinema, 201-218.

12 During and after the apartheid era some scholars refused to capitalise the first letter of the term Coloured in order to indicate both opposition to the enforced classification of people into racial and ethnic categories, and a distaste for ethnocentric values. The practice was further justified by the assertion that, since the word was not derived from a proper noun, there was no need to capitalise it. Some are now of the opinion that, because of the "normalisation" of South African society in the post-apartheid period, it is normal practice to capitalise the "C word". Mohamed Adhikari 2005. Not White Enough, Not Black Enough: Racial Identity in the South African Coloured Community. Athens, OH: Ohio University Press) quotes a journalist, Paul Stober: "As a distinct ethnic group with over three million members, we deserve a capital letter." Adhikari continues, "It is also an indication of the rapid change identity is experiencing in the post-apartheid environment, as old sensitivities die down and as new concerns and agendas impinge on people's consciousness" (Adhikari, 2005, xv).

13 This difficulty in defining gangs is not confined to the South African context. It is also not limited to a discussion of gangsterism as a phenomenon, but with definitions in general. Among social scientists in the academic world, definitions are most often determined in terms of variables, many of which are derived from social learning theory. Other studies use personal-biographical characteristics, and still others depend on observations and reports of various kinds.

14 Gastrow, Peter 1998. Organized Crime in South Africa. An assessment of its nature and origins. ISS Monograph Series No. 28. Halfway House: Institute of Security Studies. 25 April 2006.

http://www.iss.co.za/Pubs/Monographs/No28/Introduction.html 
ther a battle over turf involving the illicit drug market, or revenge killings associated with gang leaders released from prison. ${ }^{15}$ One township known for gangsterism in the past, Manenberg, has experienced a sudden increase in gang-related shootings and killings after some years of relative peace and calm. This particular upsurge in gangsterism underscores a very important point, namely that gangsterism is a systemic phenomenon that is deeply rooted in certain communities on the Cape Flats.

\section{Gangs: A Gender Perspective}

Elaine Salo ${ }^{16}$ makes a very important contribution to the debate concerning the formation of gangs when she looks at it from a gender perspective. Acknowledging the structural analyses of gangs by authors such as Pinnock, she argues that "they offer only part of the explanation for the existence of gangs in the complex social landscape of urban African townships." She continues:

Gang members have other gendered identities that are embedded within the generational continuity of a household and that are woven within the richly textured social expanse of communal relationships and networks within the township. They are also sons, brothers, husbands, fathers, lovers, friends and social mentors. These other gendered identities overlap, sometimes conflict with, and ultimately shape their identities as gang members. Gangs are not just the social expression of mainstream society. They are also one of the means through which gendered personhood is affirmed and through which communities are forged and reproduced. They provide some of the social and economic capital through which households are sustained, and they uphold the informal system of township justice. They embody the structural bond between the dominant social centre and its peripheral communities, and they are the expression of the cultural and economic contradictions between the two.

Salo presents the following argument:

I argue that whilst the dominant structural factors of racial and economic marginalization are important, one has to look beyond these factors and examine the gendered and generational relationships within the gang as well as between the gang and the community they reside in, in order to obtain a more textured picture of ganging practices on the Cape Flats.

For Salo membership of a gang is not only about resistance and economic survival, it is also about asserting gendered identities as heterosexual men who do not possess the "dominant material and symbolic capital" to affirm their heterosexual masculinity, such as a professional education, a permanent job, or the economic ability to support a wife and dependants. ${ }^{17}$ In a township where, according to the South African census of 2000, unemployment is around $30 \%$ and working-class Coloured men lack the appropriate educational skills to compete for better-paying jobs, it becomes extremely important to "earn" respect and recognition as persons identified as breadwinners and heads of households. One also has to understand how Coloured women had become the "unintended beneficiaries" of apartheid

15 Cf. "Revenge or drug turf behind gang war", The Argus, 7 April 2006; "Gangs battle for tourist drug market", The Argus, 2 November 2006; "Gang turf war rips through Cape Flats streets", The Argus, 3 November 2006.

Field, Sean 2001. "Disappointed Men: Masculine Myths and Hybrid Identities in Windermere." In Morrell, Robert (ed.), Changing Men in Southern Africa. Pietermaritzburg: University of Natal Press, 211-224. He writes about two men, one classified "African" and the other classified "Coloured" who were childhood friends growing up in Windermere in Cape Town, and whose struggle to construct a positive sense of masculine identity was hindered under apartheid. "While growing up in Windermere, their choices were restricted to the dominant masculine roles of 'the gangster', 'the sportsman' or 'the working man'. At various moments in their lives they experienced disappointment when masculine myths of potency could not be attained through these roles." (op. cit., 212) 
racial legislation, firstly, through "the bureaucratic assumptions about family formation that informed the state social security programme, and secondly through the specific feminization of the industrial workforce in the Western Cape urban economy."18

According to Salo, the emasculation continues in the contemporary post-apartheid period, as the dominant definition of masculinity shifts to one that emphasises the economic roles of men. These township men continue to be excluded from the labour market because of their low levels of education and their lack of appropriate cultural capital. They still cannot become breadwinners in their families. ${ }^{19}$

Given the historic context and the present realities, "emotional toughness" amongst township men is "valorised" and colloquially referred to as "making strong bones". ${ }^{20}$ Their display of manhood finds expression in their emotional and physical ability to withstand a (progressive) cycle of gendered, economic and racial denigration. "They learned to bury emotional sensitivity in self-deprecating humour and to withstand the everyday erosion of dignity and respect." ${ }^{21}$ An alternative ideology of masculinity has been reconfigured in the local context and informs ganging practices and some men's authority and agency as gang leaders.

It is clear from this perspective that many men and young boys have been "pushed" to the margins, the edges of life, of their communities. One could employ the term "double marginalisation" 22 here. Having been marginalised as part of the "non-White" section of the

18 Salo op. cit.: "In the first case, the apartheid state assumed that all households conformed to the westernized two-parent family norm where fathers and mothers fulfilled stereotyped gendered roles. Consequently child welfare grants were payable to women as mothers and public housing only provided to families with women and children. Secondly, within the economic sphere, the feminization of the labour force in the textile industry, together with the impact of the Coloured Labour Preferential policy in the Western Cape resulted in coloured women being the preferred workers. Until the early $1990 \mathrm{~s}$, adult women held relatively powerful economic statuses within these townships as the conduits to scarce economic resources and shelter ... Men, on the other hand, could not realise the vision of masculinity (embodied in white, Afrikaner control of the state apparatus, and upper class, mainly white men's control of economy in the public sphere, and their easy access to employment that ensured their ability to support a dependent wife and children in the private home) during the apartheid era. Discriminatory racial policies such as job reservation, trapped them in seasonal, unskilled, low paying jobs as labourers in the fishing, construction and service industries. The dominance of feminised industries locked them out of the few opportunities for permanent employment."

19 This is confirmed in an interview I had with Pastor Henry Wood (6 June 2006), who pastors at a church in Manenberg at the venue that used to be the headquarters of the Hard Living Kids, one of the biggest and most notorious gangs in the past. According to Wood, one of the reasons "reformed gangsters" return to crime and gangsterism is their inability to "put something on the table" for their families. As a member of the gang, such a man is "looked after", and supplied with the means to provide for family or dependants. This view is echoed by another pastor with years of experience in working with gangsters in the Ravensmead community, pastor Tom Klein, whom I interviewed on 28 November 2006. Cf. also Standing, André. 2003. "The social contradictions of organized crime on the Cape Flats." Occasional Paper 74, June 2003. Institute for Security Studies. Making a "jong", gangs' rites of passage or initiation ceremonies, always involve some form of infliction of pain. For example, members of a gang, armed with leather belts, wooden clubs and planks form a "corridor" through which an initiate has to run while being beaten by the members. After this he receives the "tjappie" (the tattoo) of the gang - without flinching - all to demonstrate that he has "sterk bene" (strong bones) - the ability to stand your man and to assist your brother when he is in trouble (in a gang war).

21 "For black men the harshness of life on the edge of poverty and the emasculation of political powerlessness gave their masculinity a dangerous edge. Honour and respect were rare, and getting it and retaining it (from white employers, fellow labourers or women) was often a violent process." (Robert Morrell 2001. "The Times of Change: Men and Masculinity in South Africa." In Morell, op. cit. 18.

22 Mokwena, Steve 1991. The Era of Jackrollers: Contextualising the rise of youth gangs in Soweto. CSVR, Seminar No 7, 1991. March 2006. http://www.csvr.org.za/papers/papmokw.htm. Cf. also Sean Field's (op. cit. 218) description of the story of Mr GB and his sense of marginalisation, questioning and doubting his 
South African population through apartheid's social engineering, they have also been marginalised through a process of social and economic emasculation in the Western Cape. We may agree with Homer U Ashby Jr. when, referring to black-on-black crime in the United States of America, he talks about "a form of internalized oppression" within the cycle of racial conditioning." ${ }^{, 3}$ Ashby continues:

Unable to retaliate effectively, the anger and rage are turned inward. The internalized oppression is both physical and mental. The resulting black-on-black violence bears witness to the internalized oppression. ${ }^{24}$

Elaine Salo helps us to get a sense of how gangs create and reproduce the meanings of personhood as well as community in the local context; how even the tattoos mark men's bodies as "physical boundaries of the local community, an alternative social and moral space in which apparently different notions of personhood, gender and style dominate."25 Faith communities should be aware of the different factors contributing to the formation and "reformation" of gangs in order to play a meaningful role in trying to find lasting solutions to the problem, as opposed to the knee-jerk, reactionary responses one usually finds when gang-related violence and killings breaks out. Faith communities, especially church communities, where women are normally in the majority, should pay close attention to "identity politics" and the idea that people have "multiple identities" ${ }^{26}$ Sensitivity is needed to the fact that "a number of masculinities" exist, and generalisation and blanket stereotyping should be avoided:

Masculinities are fluid and should not be considered as belonging in a fixed way to any group of men. They are socially and historically constructed in a process which involves contestation between rival understandings of what being a man should involve. ... Masculinities are constantly protected and defended, are constantly breaking down and being recreated. For gender activists this conceptualisation provides space for optimism because it acknowledges the possibility of intervening in the politics of masculinity to promote masculinities that are more peaceful and harmonious. ${ }^{27}$

This optimism should be shared by faith communities too. One suggestion may be to focus more on the "partnership" between men and women in the mission of God in this world. ${ }^{28}$

In the next section I will show how the economic deprivation and systematic impoverishment has led to the development and establishment of a so-called "criminal economy" on the Cape Flats, which further resulted in large-scale community support for those who have become part of a "criminal elite".

\section{The Criminal Economy of the Cape Flats - Life at the Economic Edges}

It is not always easy to separate politics and economics. Apartheid policy was aimed at keeping Blacks and Coloureds economically dependent. One result of this social engineer-

masculinity and whether he was "man enough" in a masculine world where certainty and assertiveness are prized qualities.

Ashby, Homer U Jr. 2003. Our Home is Over Jordan: A Black Pastoral Theology. St. Louis, MO: Chalice

Press, 7.

bid.

Salo ibid.

Morell op. cit. 11 .

Op. cit. 7.

28 MacMaster, Llewellyn, LM 1994. "Women and Men in Church Leadership in Africa Today." In Njorge, J Nyambura and Paraic Réamonn (eds.) 1994. Partnership in Mission in Africa Today. Studies from the WARC, Number 29, 1994, WARC: Geneva. 
ing was large-scale illiteracy as well as unemployment. In 1991 Steve Mokwena writes that young people comprised more than $30 \%$ of an estimated four to five million unemployed people in the country:

Under-educated black school leavers experience their marginalisation most acutely in their economic powerlessness when confronted by contracting job markets and virtual denial of any legitimate wealth-creating capacity. In this context the creation of alternative criminal youth gangs, not surprisingly, provides an obvious and welcome substitute. ${ }^{29}$

Young people in the Black African townships develop their own means of survival by, amongst other things, the practice of ukutabalaza. Mokwena quotes a young Soweto man:

It is when you do all that is in your power to get money. You see, the world is bad place because it is built on money ... when you don't have money you are just a dog. ${ }^{30}$

Ukutabalaza may refer to honest ways of making money, but in the townships it generally refers to illegal and criminal methods. These include theft, muggings and housebreaking. It may also include the more serious crimes like vehicle theft and hijackings, bank and transit robberies where more sophisticated crime syndicates are involved. Notorious criminals are often viewed as heroes and role models. ${ }^{31}$

Not only are these economic factors part of the root causes of gangsterism, they also play a major role in sustaining gangs. Gangs operate within communities affected by poverty, where they become providers of the basic needs of many people in the form of food, payment of rent and school fees. It was therefore not surprising when a woman from Valhalla Park shouted on television with the arrest of well-known leader of the Firm at the time, Colin Stansfield, in 2000: "Wie gaan nou vir ons kinders sorg?" [Who will take care of our children now?].

Kinnes also writes how Rashaad Staggie, leader of the Hard Livings, operated a loan scheme from a shop between 1989 and 1996:

He was able to provide bread and other basic necessities to people in need. As a blatant tactic, he would also drive through the streets and throw money that was illegally obtained from his moving car to ensure that people would continue to support him. ... The act of providing for the community is a stepping stone in gaining control of the community to the point where gangsters are able to commit crime without fear of being reported. Gangs in the Western Cape have succeeded in doing this by effectively exploiting the economics of poverty. ${ }^{32}$

With reference to these kinds of acts of "philanthropy", André Standing wrote his thoughtprovoking paper to try and explore the significant degree of community support certain prominent members of organised crime on the Cape Flats receive. ${ }^{33}$ Standing speaks of "the criminal economy" of the Cape Flats that is "substantial, its various boundaries blur with other economic and social activities and it involves thousands of people." ${ }^{34}$ The Cape Flats is home to a vast number of people and families who "precariously exist outside the formal economy, being socially excluded", ${ }^{35}$ characterised by high levels of unemployment and poverty. These conditions provide the background to the operations of the so-called criminal elite, "roughly 10 to 20 men who lay claim to being in control of significant areas of the

\section{Ibid. \\ Ibid.}

31 This hero worshipping is also described by Gayton McKenzie, a reformed former leader of a gang of robbers. Cf. McKenzie, Gayton 2006. The Choice: The Gayton McKenzie Story. Cape Town: X-Concepts Books.

32 Kinnes ibid.

33 Standing $i b i d$.

34 Ibid.

35 Ibid. 
Cape Flats. ${ }^{36}$ These men own one or several houses on the flats that operate as shebeens, but have also in recent times bought properties in some of the more affluent areas of Cape Town. The criminal elite control the distribution and sale of alcohol and drugs in their areas, while some control a local sex industry, export stolen cars, sell stolen firearms and also arrange for the theft of goods from factories and warehouses to be resold in their domains. Their business portfolios further include hotels, night clubs, public transport, garages, shops and commercial fishing boats. Not all leaders in the criminal economy are gang members, but members of numerous street gangs form the base of each criminal domain. Gangs would generally establish affiliations with prominent criminal elites, benefiting both sides. Because some of these crime bosses have allegedly also developed close relations with members of the police and even politicians, many people in the community see them as being untouchable. Standing provides three reasons why organised crime gains support from people on the Cape Flats, namely "by providing income, via community governance and via acts of philanthropy":

[T] he income of the criminal economy represents a rational response to an economic crisis. Cheap stolen goods and profits from activities such as drug dealing receive popular support because they cushion the effects of poverty. This leads to a situation in which the activities of organised crime are tolerated by a substantial proportion of the community and subsequently criminality loses much of its deviant anti-social connotations. Yet the dynamics of the illicit economy undermines and exacerbates the social and economic condition of the Cape Flats. It perpetuates gross inequalities and restricts mobility. ${ }^{37}$

It seems as if the new South Africa has not necessarily brought relief from poverty and crime for the Coloured population of the Western Cape - a point already highlighted in the previous section. Wrestling with the question of whether the crime problem in the Western Cape and the Northern Cape is rooted in the Coloured population, Ted Legett writes:

Coloured people are far more likely to be murdered than any other group. ... Coloured people are also over-represented in the nation's prisons, according to the Department of Correctional Services, making up $18 \%$ of the national prison population while representing only $9 \%$ of the national population. ... Being incarcerated may also lead to life-long gang allegiances that keep inmates locked into criminal lifestyles even after release. ... Since 1994, unemployment has increased only $19 \%$ in the black community, compared to $35 \%$ in the coloured community. ...The Cape Flats are characterised by high concentrations of jobless people who need cash to pay rent, purchase food, and pay for services. Disadvantaged under apartheid, they may still feel disadvantaged under democracy, and have no revolutionary hopes that the situation will change drastically in the future. ${ }^{38}$

Crime bosses also gain community tolerance and respect by performing functions traditionally associated with the state, providing "governance from below". These functions include the settlement of disputes (for example, brokering peace during conflicts among residents, gangs or local businesses), as well as providing a degree of social protection, either passively (merely the presence of a powerful man in the area) or more actively (like ordering retribution against someone who has harmed or threatened a resident in his area).

$\mathrm{Salo}^{39}$ relates a story from Manenberg in 1997 that further illustrates this role played by crime and gang bosses. When the Naughty Boys accused one of the members of the Dixie

\footnotetext{
36 Ibid.

37 Op. cit.

38 Legget, Ted 2004. "Still Marginal. Crime in the Coloured Community." Crime Quarterly, No 7, 2004. 25 March 2006. http://www.iss.org.za/pubs/CrimeQ/No.7/Leggett2.htm 
Boys of stealing wheels from a car that belonged to one of their members and vowed that they would take revenge, they sent a delegation to Paul, leader of the Dixie Boys, to inform him about their plans. Meeting them in the presence of some of the "moeders" ("mothers") and a few older men, Paul negotiated with the delegation. The outcome of this meeting was the punishment meted out to the member accused of the theft by his own gang, warding off a potentially ugly gang conflict and thereby averting a more serious threat to the well-being of the residents of that particular street. ${ }^{40}$

The third reason for community support, according to Standing, stems from the criminal elite's "disposition towards acts of philanthropy". ${ }^{41}$ Residents turn to gang bosses for money to help them with day-to-day costs of living. Gang bosses are reported to have assisted churches with projects; they sponsor many local football teams and teams competing in the Coon Carnival. The ecumenical secretary of the Western Cape Provincial Council of Churches (WCPCC) articulates the frustration of religious leaders with this situation:

The church has responded to the economic and social crises of the Cape Flats emotionally, whereas the criminal elite have responded materially by providing the rudiments of an alternative welfare system. ${ }^{42}$

Standing argues that it is a mistake to consider the only motive of philanthropic criminals as economic self-interest. It is also about community glory:

The random handouts, the ability to support families, the Church or the football team, are all activities that provide local celebrity status. In such cases, we may concur that philanthropy may be symbolic of a depressing reality of life on the Cape Flats, for in impoverished communities that provide few cases of celebrated successes, the crass antics of the obscenely wealthy crime boss can easily assume centre stage. ${ }^{43}$

It is clear that the criminal elite on the Cape Flats operate within a context of undesirable socio-economic conditions, where unemployment and poverty are daily realities. The fact remains that there are social contradictions inherent in the criminal economy that is not a fringe activity but rather a core dimension of the society:

Thus, the surface benefits of criminal income can be contrasted with exploitation and a gross polarisation of wealth. The benefits if philanthropy and community governance can be contrasted with criminal elite who have created an environment favourable for the continuation of their business empires. The overarching contradiction is that the criminal economy perpetuates the conditions it seeks to ameliorate - poverty, social fragmentation and a lack of efficient, just governance. ${ }^{44}$

How do faith communities in general and the Christian church in particular respond to this situation?

40 Salo (op. cit.) draws the following conclusion from this incident: "Residents preferred the gang's kangaroo style court to a formal investigation by the police. The police may have investigated the car theft, but they would also have learned of other illegal economic activities that the impoverished township residents necessarily rely on to survive. The 'Boere' or the 'Boers', as the police were commonly called in the township, were considered to be part and parcel of the township communities' systematic denigration. Most residents acknowledged that theft was unpleasant. However, they made a moral distinction between theft committed against the local poor (considered to be morally reprehensible), who could ill-afford any material loss, and the nameless wealthy who were safely insulated from the ravages of poverty and who seemed to care little about the less well-off township dwellers (considered unpleasant, but a necessary aspect of survival)."

Op. cit.

Quoted by Standing op. cit.

43 Standing op. cit.

44 Ibid. 
In the last section I will indicate some of the issues I think should be addressed from a pastoral-theological perspective.

\section{Pastoral-theological Response}

The following are not necessarily in order of priority or importance.

1. Gangsterism is a phenomenon in some communities on the Cape Flats that has caused a lot of pain, suffering and continuous fear amongst residents there. It should never be glorified or accepted as a given reality that cannot be changed. The majority of residents of the Cape Flats in general and young people in particular do not belong to gangs. This positive fact should encourage the church, government and community workers to work collectively to eradicate gangsterism in these communities.

2. Gangsterism contradicts the notion of human dignity that is embodied in the fact that people are created in the image of God. We have shown how socio-economic and political conditions have contributed to the formation and existence of gangs on the Cape Flats. People belonging to gangs have come to believe that they have no other option, that it is, so to speak, their destiny as human beings.

3. A holistic approach to pastoral care is necessary. Pastoral care from a more clinical pastoral perspective, or the so-called psychological paradigm, with a strong focus on the individual and his or her needs, will not be adequate within a context of gangsterism. Gangsterism is clearly a systemic phenomenon deeply rooted in the history of the Cape Flats and its people and affecting not only certain individuals, but families and whole communities. Since this is the case, faith communities in general and pastoral carers in particular will have to consider the entire picture or context, including individual, communal, socio-economic and political facets, in their attempts to play a meaningful role in trying to address and to eradicate gangsterism. In this regard one has to look at models of pastoral care proposed by several pastoral theologians that capture this vital aspect. Julian Müller ${ }^{45}$ proposes an eco-hermeneutic model that implies the interpretation of God's salvation to people within the total reality of their daily existence. Larry Kent Graham's psychosystems approach to pastoral care and counselling ${ }^{46}$ refers to the "reciprocal interplay between the psyche of individuals and the social, cultural, and natural orders. ... It joins microsystemic and macrosystemic arenas of experience. ... The basic thesis of this book is that to care for persons is to create new worlds; to care for the world is to build a new personhood". ${ }^{47}$ In this regard Bonnie J. Miller-McLemore proposes the term "living human web" as a better term than Anton Boisen's ${ }^{48}$ powerful metaphor of the "living human document" to emphasise the point that "public policy issues that determine the health of the human web are as important as issues of individual emotional well-being". ${ }^{49}$ She continues: "[P]sychology will serve a less exclusive (though still important) role, while social sciences such as economics or political science will become powerful tools of interpretation". ${ }^{50}$ This aspect is also an integral part

45 Müller, Julian, C 1991. "Pastoral Care in Post-apartheid South Africa." Praktiese Teologie in SA 6(2) 1991, 184-192.

46 Graham, Larry Kent 1992. Care of Persons, Care of Worlds: A Psychosystems Approach to Pastoral care and Counseling. Nashville, TN: Abingdon Press.

47 Op. cit., 13.

48 Miller-McLemore, B 1993. "The Human Web: Reflections on the State of Pastoral Theology." Christian Century, April 7, 1993, 366-369. 19 April 2006. http://www.religion-online.org/showarticle.asp?title=315 
of Daniël Louw's development of a basic theory for pastoral care, which he identifies as one of the major shifts in pastoral care "away from unilateral intra-psychic dynamism, with its one-sided emphasis on autonomy and self-realisation, towards a psychosystemic dynamism, which emphasises the network of connections and structures within a social and cultural context". ${ }^{51}$

4. A re-appreciation of pastoral theology as public theology will help us to move beyond the gate or wall, to be or become "bi-lingual" (Walter Brueggemann ${ }^{52}$ ), understanding the politics of oppression and empowerment inherent in pastoral care and counselling (Edward Wimberly ${ }^{53}$ ) in communities such as those on the Cape Flats. We understand that "scratching the surface" will not solve the problem and shouting only for shortterm, heavy-handed intervention is exactly what that is, a short-term solution. This needs to be combined with medium- and long-term socio-political action that aims at eradicating the conditions that make it easy for people, especially young people, to be drawn into gangsterism.

5. In our description of pastoral care as remembering and re-membering (John Patton ${ }^{54}$ ), we see the church as "Family of God", where we understand and experience the grace of God; where we extend that grace to, and share it with, "outsiders" and welcoming "strangers" (read gangsters) with biblical hospitality. As Family of God we offer "relational refugees" (Edward Wimberly) ${ }^{55}$ our love and friendship, "tattoos and all", as people created in the image of God. This will, amongst other things, mean that we will have to positively affirm men and boys in order to restore their sense of dignity and worthiness as fully human, despite the adverse socio-economic and political circumstances that have led to their emasculation. This can only be done within a context of relationality and responsibility. ${ }^{56}$

6. One main feature that emerged in my interviews with people working with gangs and a former member of a gang, is the willingness of Christians, pastors or community workers to "walk with" a gangster or gangsters. In this I read a willingness to accept the person as a person, as well as the willingness to leave our comfort zones, to take the risk, developing relationships that will put us in a position to help gangsters to appreciate or re-appreciate the God-given gift of real personhood. Edward Wimberly's book on sacred identity formation ${ }^{57}$ may be a helpful resource in this regard. The emphasis of this book is on:

... how we have appropriated Scripture and theology to understand that we have been affirmed by God despite our being recruited into negative self-images because of racism and oppression. ${ }^{58}$

51 Louw, Daniël J 1998. A Pastoral Hermeneutics of Care and Encounter. A theological design for a basic theory, anthropology, method and therapy. Cape Town: Lux Verbi.BM, 13.

Wimberly, Edward P 2005. African American Pastoral Care and Counseling. The Politics of Oppression and Empowerment. Nasville, TN: Abingdon Press.

54 Patton, John 1993. Pastoral Care in Context. An Introduction to Pastoral Care. Louisville, KY: Westminister John Knox Press.

55 Wimberly, Edward P 2000. Relational Refugees. Alienation and Reincorporation in African American Churches and Communities. Nashville, TN: Abingdon Press. 
"Walking with" people would imply for me what Wimberly proposes when he highlights the importance of conversations between people as a "meaning-building process", recognising that too many of the conversations that children and young people on the Cape Flats are part of are negative, "problem-saturated and deficit-laden" and "disjointed". ${ }^{99}$ Pastoral caregivers on the Cape Flats should look for, and be sensitive to, windows of opportunity to engage in positive conversations with gangsters as well as the people adversely affected by gangsterism, helping them to "work through internalized recruitment into negative identities" $" 60$ by re-editing and re-authoring their stories through a process of sacred identity formation. 